University of Pennsylvania Carey Law School

Penn Carey Law: Legal Scholarship Repository

Faculty Scholarship at Penn Carey Law

6-15-2022

\title{
Municipal Fiber in the United States: A Financial Assessment
}

Christopher S. Yoo

University of Pennsylvania Carey Law School

Jesse Lambert

Goodwin Proctor LLP

Timothy P. Pfenninger

DLA Piper

Follow this and additional works at: https://scholarship.law.upenn.edu/faculty_scholarship

Part of the Infrastructure Commons, Internet Law Commons, Law and Economics Commons, Policy

Design, Analysis, and Evaluation Commons, Public Economics Commons, and the State and Local

Government Law Commons

\section{Recommended Citation}

Telecomm. Pol., Vol 46, Iss. 5 (Jun. 2022).

This Article is brought to you for free and open access by Penn Carey Law: Legal Scholarship Repository. It has been accepted for inclusion in Faculty Scholarship at Penn Carey Law by an authorized administrator of Penn Carey Law: Legal Scholarship Repository. For more information, please contact PennlawIR@law.upenn.edu. 


\title{
Municipal Fiber in the United States: A Financial Assessment
}

\author{
Christopher S. Yoo, ${ }^{*}$ Jesse Lambert, ${ }^{\dagger}$ and Timothy P. Pfenninger ${ }^{\star}$
}

\begin{abstract}
Despite growing interest in broadband provided by municipally owned and operated fiber-to-the-home networks, the academic literature has yet to undertake a systematic assessment of these projects' financial performance. To fill this gap, we utilize municipalities' official reports to offer an empirical evaluation of the financial performance of every municipal fiber project in the U.S. operating in 2010 through 2019. An analysis of the actual performance of the resulting fifteen-project panel dataset reveals that none of the projects generated sufficient nominal cash flow in the short run to maintain solvency without infusions of additional cash from outside sources or debt relief. Similarly, $87 \%$ have not actually generated sufficient nominal cash flow to put them on track to achieve long-run solvency. In addition, $73 \%$ generated negative nominal cash flow over the past three fiscal years, leaving them poorly positioned to make up their deficits and causing them to fall farther into debt. An assessment based on the net present value of these projects' operating cash flow indicates that $53 \%$ of projects would not be on track to breakeven even assuming the theoretical best-case performance in terms of capital expenditures and debt service. Close analysis of these projects' performance reveals that revenue generation likely plays a more important role in generating cash flow than efficiency in construction costs or operating efficiency.
\end{abstract}

Keywords: municipal broadband, government-owned network, fiber to the home, cash flow, net present value, bond financing

\section{$1 \quad$ Introduction}

Municipal fiber networks have become an increasingly hot topic in the U.S. The

COVID-19 pandemic heightened public awareness of the critical importance of broadband

connectivity. Support for bringing as many people online as possible led to the inclusion of $\$ 65$

billion in funding in the Broadband Infrastructure Framework ("BIF") recently enacted into law.

\footnotetext{
John H. Chestnut Professor of Law, Communication, and Computer \& Information Science and Founding Director of the Center for Technology, Innovation and Competition, University of Pennsylvania.

$\dagger \quad$ Associate, Goodwin Procter LLP.

* Associate, DLA Piper LLP (US). The authors would like to thank Timothy von Dulm, Mia Wells, William Kirton, Andrew Eichen, Sara Hansson, and Sophia Rappleye for their assistance with this project.
} 
This includes $\$ 42.5$ billion in grants to state and local governments for extending broadband infrastructure in unserved and underserved areas, improvements to data collection and mapping, and implementation of broadband adoption programs. The impending issuance of these grants makes understanding how to get the most out of this limited funding even more important. This legislation has been referred to as technology neutral, indicating that it does not favor any technological approach to bringing more people online.

State and local governments will soon confront important decisions about the best uses of this limited funding.. The role played by municipal broadband is likely to be controversial. For example, although President Biden initially proposed that broadband infrastructure funding prioritize broadband networks operated by local governments, nonprofits, and cooperatives, that provision was omitted from the final BIF legislation. In addition, municipal broadband received mixed support during the November 2020 election, during which some U.S. cities approved ballot initiatives authorizing cities to proceed with municipal broadband projects, while other cities rejected them. ${ }^{1}$

States, cities, and federal agencies evaluating whether to fund municipal fiber projects would benefit from empirical analyses of the success and failure of past efforts. To date, the literature has drawn mixed conclusions on whether municipal fiber promotes economic growth (Holt and Jamison, 2009; Kenny and Kenny, 2011; Guidry, Carson and Haon, 2012; Oh, 2019; Ford and Seals, 2021) or improves price and service quality (Talbot, Hessekiel, and Kehl, 2018; Chao and Park, 2020; Ford, 2020). A more fundamental limitation of these analyses is that benefits only represent half of the equation: The other side of any cost-benefit analysis requires

\footnotetext{
$1 \quad$ Voters in Denver, Berthoud, and Englewood, Colorado, authorized their cities to opt out of a state law prohibiting municipal broadband. Voters in Kaysville, Utah, and Lucas, Texas, rejected municipal fiber projects (Gonsalves, 2020).
} 
considering whether municipal fiber projects are likely to be self-sustaining or whether they are likely to generate deficits that cities will have to cover with funds from general tax revenue. Such support may require either one-time subsidies for capital construction or ongoing annual support for projects that continue to generate annual cash flow deficits. Cities weighing the tradeoff between funding municipal fiber projects or other potential priorities need the clearest possible picture of their likelihood of success.

This article is the first to take a more systematic approach using a unique dataset comprised of the lifetime financial performance of every municipal fiber project in the U.S. operating in 2011 that provided annual financial reports for their fiber operations. It represents the only analysis to date that evaluates the financial performance of the entire universe of municipal fiber projects in the U.S. based on the highest quality data issued by government sources and metrics generally accepted by the financial community for evaluating viability.

\section{Literature review}

The academic study of government-owned telecommunications networks began with the debate surrounding the 1912 nationalization of the British telephone system (e.g., Holcombe, 1911). The UK government's acquisition of British Telecom touched off a wave of nationalization that led to nearly universal public ownership by the 1970s, with the United States being the notable exception (Noll, 2000). ${ }^{2}$ The 1984 denationalization of British Telecom led to a global privatization movement that sparked further study of whether private ownership improved these firms' financial performance and service quality (e.g., Bortolotti et al., 2002).

2 Even the U.S. experimented with government ownership during World War I (Janson and Yoo, 2013). 
Municipal Wi-Fi enjoyed a brief paroxysm of support during the mid-2000s, which generated another wave of scholarship (e.g., Jassem, 2010).

Commentary and popular attention have increasingly focused on municipal fiber. For example, the Government Accountability Office (2014) published a report analyzing fourteen federally or municipally funded fiber projects, while the Executive Office of the President (2015) also issued a report conducting case studies of six municipal fiber projects. Both studies focused on the impact of these projects on download speeds and prices without analyzing their sustainability. The small number of empirical analyses of these networks' financial performance have generally been published as advocacy pieces rather than articles in scholarly journals (compare Scott and Wellings, 2005; with Lenard, 2004; Balhoff and Rowe, 2005; Davidson and Santorelli, 2014). There has been only one study of municipal fiber projects' financial performance published in an academic journal, and it examines five years of operating income for a single project (Beard et al., 2020). Altogether, these studies focused on selected case studies, were based on short-term snapshots rather than comprehensive assessments of the projects' entire lifespans, and analyzed operating income, which, as we will discuss in greater detail below, is not regarded as the most probative measure of viability. No prior scholarly work or government publication has systematically assessed the entire universe of U.S. municipal fiber projects, evaluated projects over their entire lifetime, nor focused on cash flow instead of income. The closest is an earlier, unpublished version of this study, which analyzed five years of cash flow for twenty projects (Yoo and Pfenninger, 2017a). ${ }^{3}$

\footnotetext{
(2017b).

For our responses to some initial reactions to this previous version of our study, see Yoo and Pfenninger
} 


\section{Bonds as the Principal Mechanism for Financing Municipal Fiber Projects}

Municipal fiber networks require significant upfront investments that typically require tens of millions of dollars. Because cities rarely have that amount of cash on hand, they generally finance such projects by issuing tax-free municipal bonds or similar debt, which allow them to borrow the cash needed for initial construction and then repay the principal and interest from the returns generated over the lifespan of the project, with the expected life of fiber optic cables to be twenty to twenty-five years and the expected life of digital switching equipment to be between twelve and eighteen years (U.S. Federal Communications Commission, 2000, Appendix B). ${ }^{4}$ Because municipal fiber projects require an initial construction period during which they do not generate significant revenue, the debt instruments financing these projects typically permit interest-only payments during a project's initial three-to-five years to give them time to ramp up. Thereafter, payments must cover a portion of the principal in addition to the accrued interest.

The bond documents for the municipal fiber projects included in this study consistently reflect the expectation that the projects would generate sufficient returns to service this debt. First, all of the bonds that provided the initial funding for these projects were issued as "revenue bonds," which are defined as bonds expected to be repaid from funds generated by a specific project or source, as opposed to "general obligation bonds," which are expected to be repaid from the city's sources of general tax revenue, such as property taxes (U.S. Securities and

\footnotetext{
4 The U.S. Internal Revenue Service $(2021,106)$ similarly places the depreciable life of distribution plant at twenty-four years and computer-based switching equipment at 9.5 years for telephone companies. The U.S. Government Accountability Office $(2012,4)$ similarly estimates that the useful life of fiber cables to be between twenty to twenty-five years. The bonds used to finance the vast majority of municipal fiber projects have terms of between twenty and twenty-five years.
} 
Exchange Commission, 2021). ${ }^{5}$ For example, Monticello characterized its initial 2008 financing as "Telecommunications Revenue Bonds" and specified that they were payable "solely from the net revenues of the FTTP project." After it defaulted on the 2008 debt, it characterized the new 2014 debt issued to finance the settlement as "General Obligation Bonds."

Second, the Securities and Exchange Commission ("SEC") requires that all municipal bonds be accompanied by an official statement that brings together all of the information that the SEC requires municipal bond issuers to disclose. The official statements for all of the municipal fiber projects that fall within this study consistently note that the debt is expected to be repaid out of revenues generated by the municipal fiber project.

Third, bond instruments for projects expected to require contributions from general funds invariably include terms specifying the schedule of payments that cities are expected to make from general revenue into reserve funds. No such terms appeared in the projects included in this study.

Fourth, the annual financial reports issued by the cities that fall within this study initially classified their municipal fiber projects as enterprise funds or independent authorities rather than governmental or internal service funds. According to Governmental Accounting Standards Board Statement No. 9 (1989), this signifies that these cities expected these projects to repay their costs from project revenue and not from taxes or interfund transfers.

Fifth, many annual financial reports state that the cities anticipated these projects would cover their costs out of project revenue and that cities would not have to make regular contributions from their tax revenue to defray project costs.

$5 \quad$ This terminology does not apply projects financed through means other than bonds, such as leases (Burlington) or certificates of participation (Salisbury and Wilson). 
None of these features would have been true had the cities that initiated projects expected the projects not to be self-sustaining and would require contributions from general revenue. All indications - the characterization of the bonds as revenue bonds, the language of the official statements, the lack of provisions requiring contributions from general funds, the way these cities accounted for their municipal fiber operations, and numerous representations in these cities' annual financial reports - underscore that the cities initiating these projects did not expect them to generate shortfalls and instead expected them to cover their costs. Indeed, supporters for the projects in Dunnellon and Salisbury envisioned that the projects would generate surpluses that would allow those cities to lower taxes.

In many cases, the projects were promoted as potential drivers of economic development. To cite perhaps the most prominent example in the U.S., supporters lauded the Chattanooga project as a "real tool for economic development" (Lohr, 2010) by creating "a high-speed information corridor allowing Chattanooga to become a hub for future research, information sharing, and job growth" (City of Chattanooga, 2006, C-3). Similar statements were made in connection with the projects in Dunnellon and Salisbury and are offered as benefits from the projects in Monticello, UTOPIA, and Windom.. To this end, Chattanooga's project began as a fiber offering to businesses before being expanded to serve residential customers. Similarly, Wilson, NC built a fiber backbone serving municipal institutions before extending the network to serve business and residential consumers. The project in Windom was principally motivated by lowering telecommunication prices for customers..

Whatever the reasons for initiating particular projects, the names of the bonds and the language included in the official statements, bond instruments, and financial reports all manifest the belief that the projects would generate sufficient revenue to cover their costs.. Even had 
these cities not expected these projects to break even, they still would benefit from an evidencebased understanding of previous projects' financial performance to help them assess the likelihood their project will require support from general tax revenue or other sources and the potential magnitude of that support. Regardless of whatever collateral benefits a municipal fiber project may create, cities must still pay the principal and interest associated with the debt incurred to build out these networks. Indeed, municipalities that initiate projects that are unable to cover their costs of debt and operations will have to make up the shortfall from general tax revenues or default on their debt, either of which would inevitably affect the cost of financing all of the city's operations, not just the municipal fiber project.

\section{$4 \quad$ Methodology and data}

The approach of this analysis is to assess municipal fiber projects' viability in both the short- and long-run. Short-run viability measures the extent to which municipal fiber projects have been able to cover their costs to date. Those that have been unable to do so necessarily had to rely on additional contributions from other sources. Long-run viability assesses the likelihood that a project will break even by the maturity date of its initial debt financing.

\subsection{Cash flow as the basis for assessing viability}

Financial analysts generally regard cash flow as the preferred basis for assessing a project's financial viability. This is because the availability of cash is what determines whether an enterprise can meet its obligations. Although existing studies and press accounts tend to focus on operating income, many profitable enterprises become insolvent because so much of their cash is tied up in illiquid assets that are not available to pay incoming bills. 
Consider the capital costs needed to build a fiber network. From a cash flow perspective, projects typically require a large cash outlay during their initial years and require less capital during their later years, as discussed above. Operating income distorts the impact of this large initial cash expenditure by amortizing these capital costs across the projects' expected lifespan as depreciation expense. The result is that the income statement radically understates the cash demands during a municipal fiber project's early years and overstates the demand on cash in later years. In addition, rapid growth often requires significant increases in working capital. These cash needs can affect solvency in ways not reflected on income statements.

Factors like these cause net income to provide an incomplete reflection of an enterprise's cash needs, which is why the Governmental Accounting Standards Board (1989) began requiring that every financial report must also include a statement of cash flow in addition to a balance sheet and income statement. It is also why financial analysts evaluate projects' likely solvency based on cash flow forecasts rather than profitability (e.g., Beaver, 1966).

\subsubsection{Actual performance: Nominal cash flow ("NCF")}

Nominal cash flow ("NCF") represents the actual cash flowing into and out of a project. $\mathrm{NCF}$ is therefore free from any uncertainty resulting from assumptions or projections. It is simply a representation of the cash collected from and spent on a given project. Our NCF analysis considers the first two components from Statement No. 9 of the Government Accounting Standards Board's four required components of cash flow statements: ${ }^{6}$

- Cash flow from operating activities (sometimes called cash flow from operations (“CFO")) represents operating revenue less operating expenses, excluding expenses that do not require an expenditure of cash, such as depreciation, plus changes in key

6 The analysis omits the latter two components, "Cash flow from noncapital financing activities" and "Cash flow from investing activities," as both are, by definition, peripheral to a project's operations. 
categories of working capital associated with operations.

- Cash flow from capital expenditures and debt service (sometimes called cash flow from financing activities ("CFFA")) represents cash used to purchase capital assets associated with the project (typically the property, plant, and equipment needed to build the fiber network), proceeds from new capital debt financing, payments of capital debt principal and interest due; and other long-term financing.

NCF can be used to evaluate a project's viability in both the short- and long-run. In the short-run, a project's NCF should be sufficient to cover its obligations during every year of its operations, with the expectation being that the debt proceeds will provide sufficient cash to cover network construction costs in the initial years of operations before a project has the chance to become profitable in later years. ${ }^{7}$ If a project is unable to meet its cash obligations and requires an infusion of additional cash from outside sources, it will have a negative cumulative NCF, where cumulative NCF is the summation of NCF to date. Put another way, a project that is not viable in the short run will have negative cumulative NCF.

Cumulative NCF can also be used to evaluate long-run solvency by measuring whether a project is on track to generate sufficient cash by the maturity date of its initial debt to retire it. More specifically, we look at each project's cumulative NCF as of 2019 and the amount it generated in the last three fiscal years for which we have complete data $(2017,2018$, and 2019) to estimate whether it is on track to pay back its debt by the maturity date of its initial debt. We use the initial debt's maturity date to assess long-run solvency because this is the date by which the municipality expected to be able to pay off all of the principal and interest needed to finance its fiber project when it initiated the project.

$7 \quad$ Accordingly, and as mentioned above, most debt instruments permit interest-only payments during a project's initial three-to-five years without requiring any principal repayment to give it time to ramp up. Thereafter, operations are supposed to generate sufficient cash to cover the principal and interest due. 
To enable comparison across the municipal fiber projects, we had to make several adjustments to CFFA to standardize the treatment of NCF. First, the vast majority of cities in this study transferred funds from other internal sources (such as loans from other funds or transfers of tax revenue from general funds) to cover cash flow shortfalls. Some of these cities treated these transfers as capital funding and included it in CFFA, which artificially inflated their NCF, while others treated them as noncapital funding that was not included in CFFA, which had no effect on NCF. For this analysis, we have excluded from CFFA transfers from internal sources because these projects are supposed to be self-supporting.

Second, we standardized CFFA to reflect how municipalities reported the debt used to finance their fiber projects. For example, a large majority carried the debt used to finance these projects on the books of their broadband divisions, while a minority opted to carry them in whole or in part on the books of their electric power divisions. In addition, some cities refinanced or defaulted on their debt for reasons that arose after the project's initiation. For this analysis, we have adjusted CFFA such that we treat all projects as if their initial debt were carried on the books of their broadband divisions without any defaults or refinancing.

The combination of these adjustments yields the following formula for Adjusted NCF, which allows these projects to be compared on an equal basis by excluding the impact of decisions regarding whether to make internal transfers or to refinance or default on the initial debt:

Adjusted $N C F(“ A N C F ")=C F O+C F F A+$ adjustment for internal transfers included in CFFA + adjustment for differences in debt financing

To be clear, ANCF, like NCF, remains a true accounting of actual cash collected and spent by a fiber project. The minor adjustments needed to make projects' NCFs truly comparable does not 
change the fact that ANCF remains a metric based on actual cash flows and does not depend on any assumptions or projections.

$\mathrm{NCF}$ is the primary basis that municipalities and their bond issuers use to forecast short and long-term solvency at the time the bonds were issued. For example, illustrations of the expected pattern of NCF are depicted in Table 1 and Figure 1, which are based on the Forecasted Statement of Operations included in Appendix F to the official statement for the 2008 Bond issued to finance the fiber project in Monticello, Minnesota. Again, this example differs from the analysis of NCF and ANCF in this study because this example is based on Monticello's projected performance, not its actual performance. ${ }^{8}$ (A comparison of Monticello's forecast and actual performance appears in Table 9 in Section 6.1.)

$8 \quad$ In these projections, adjusted NCF is the same as NCF because the projections necessarily do not include any unexpected deviations that projects unexpectedly deployed that were not originally envisioned by the plan (e.g., transfers, refinancing). 
Table 1:

Forecast annual and cumulative NCF for Monticello, 2008-2015

\begin{tabular}{|c|c|c|c|c|c|c|c|c|}
\hline & 2008 & 2009 & 2010 & 2011 & 2012 & 2013 & 2014 & 2015 \\
\hline Forecast cash flow from operating activities & $(468,885)$ & $(2,016,902)$ & $(549,531)$ & 436,569 & 879,246 & $1,586,317$ & $1,918,825$ & $2,213,870$ \\
\hline Forecast additions to broadband plant & $(10,961,191)$ & $(3,575,820)$ & $(2,363,979)$ & $(726,031)$ & $(624,904)$ & $(1,265,741)$ & $(434,799)$ & $(404,149)$ \\
\hline Forecast by financing activities & $25,094,060$ & 0 & 0 & 0 & 0 & $(70,000)$ & $(220,000)$ & $(380,000)$ \\
\hline Forecast annual NCF & $13,663,984$ & $(5,592,722)$ & $(2,913,510)$ & $(289,462)$ & 254,342 & 250,576 & $1,264,026$ & $1,429,721$ \\
\hline Forecast cumulative NCF & $13,663,984$ & $8,071,262$ & $5,157,752$ & $4,868,290$ & $5,122,632$ & $5,373,208$ & $6,637,234$ & $8,066,955$ \\
\hline
\end{tabular}

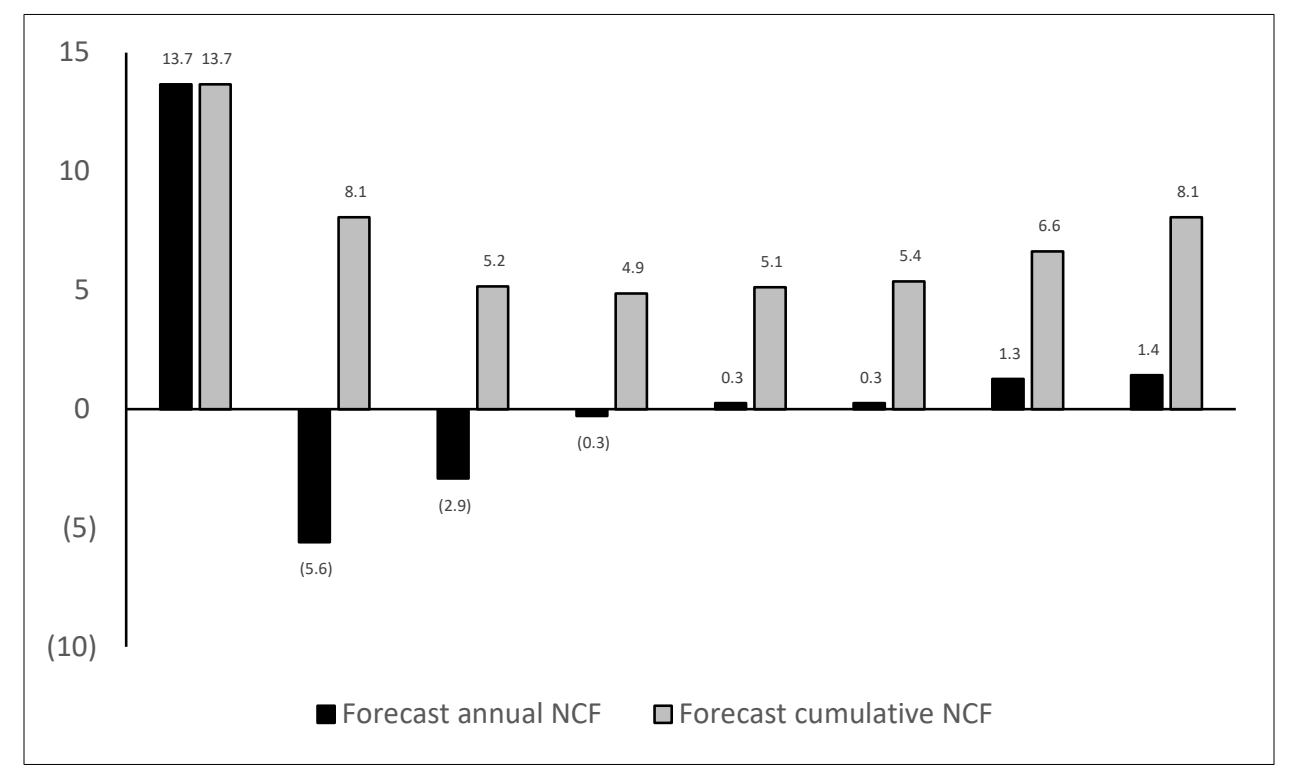

Figure 1: Forecast annual and cumulative NCF for Monticello, Minnesota, years 2018-2015 (\$ million) 
The forecast projects positive NCF in year one because of the bond proceeds, negative NCF during years two through four due to the slow startup of operations and the early capital required to build the network, and increasingly positive NCF starting in year five. Regarding short-run solvency, the bond proceeds are forecast to be large enough to ensure that cumulative NCF remains positive even during the initial years of NCF deficits. After year four, the project is expected to generate positive annual NCF that is sufficiently large to allow the project to cover its obligations during every year of operations and to pay off its debt when it matures. As we shall see, Monticello fell far short of its projected $+\$ 8.1$ million cumulative NCF surplus by 2015, instead generating a (\$4.7 million) deficit.

\subsubsection{Theoretical performance: Net present value ("NPV") of cash flow from operations ("CFO")}

Another common approach to estimating the value of a project is capitalizing its income. One standard way of doing so is calculating the project's net present value ("NPV") by summing the project's annual CFO, discounted by the project's weighted average cost of capital ("WACC"), and subtracting its overall project cost. This approach sets aside any shortcomings in the actual approach employed to finance the project and focuses exclusively on the strength or weakness of a project's operating performance. In many ways, this analysis represents a bestcase scenario based on the assumption that the project made the optimal decisions regarding capital expenditure and debt financing.

With that said, unlike the NCF and ANCF analysis described above, which is based solely on these projects' actual performance, an assessment of a project's NPV requires a number of assumptions concerning future growth (if any) and each project's expected lifespan. Thus, the NPV analysis contains some projection-related risks not associated with an analysis of 
NCF or ANCF. Nevertheless, NPV analysis remains the best tool for a municipality to use when considering the financial viability of a fiber project based on solely on its expected operating efficiency.

As relevant here, if NPV is greater than or equal to zero as of 2019, the project has already broken even and will remain viable so long as CFO does not turn negative in the future. If NPV is negative as of 2019 , the deficit can be divided by the years remaining until maturity of the initial debt to determine the annual discounted CFO needed for the project to break even. This can be compared to the project's average annual discounted CFO in recent years to assess whether the project's recent performance is sufficient to make up that shortfall by the maturity date. As with the cumulative NCF approach to evaluating long-term solvency, we use each project's performance over the past three fiscal years $(2017,2018$, and 2019) to measure its ability to make up any shortfalls without additional contributions from general revenues.

Sample forecasts are presented in Table 2 and Figure 2, which like Table 1 and Figure 1 are based on Appendix F of the official statement accompanying the 2008 Bond issued to finance the fiber project in Monticello, Minnesota. As before, this illustration is based on Monticello's projected performance, not its actual performance. (A comparison of Monticello's forecast and actual performance appears in Table 10 in Section 6.2.) 
Table 2:

Forecast annual and cumulative discounted CFO for Monticello, 2008-2015

\begin{tabular}{|c|c|c|c|c|c|c|c|c|}
\hline & 2008 & 2009 & 2010 & 2011 & 2012 & 2013 & 2014 & 2015 \\
\hline Project cost & $(26,445,000)$ & & & & & & & \\
\hline Forecast CFO & $(468,885)$ & $(2,016,902)$ & $(549,531)$ & 436,569 & 879,246 & $1,586,317$ & $1,918,825$ & $2,213,870$ \\
\hline NPV & $(26,913,885)$ & $(28,804,494)$ & $(29,287,360)$ & $(28,927,773)$ & $(28,248,916)$ & $(27,100,828)$ & $(25,799,049)$ & $(24,391,152)$ \\
\hline
\end{tabular}

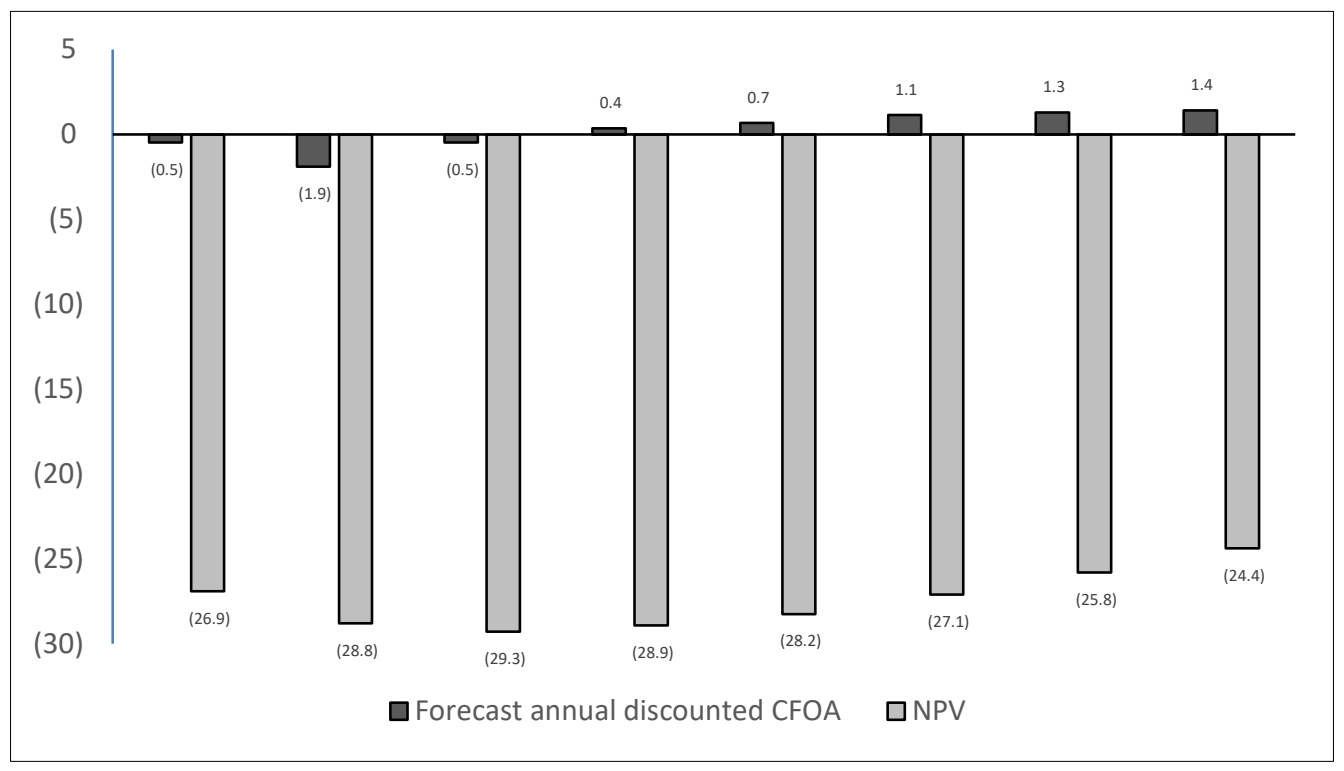

Figure 2: Forecast annual and cumulative discounted CFO and NPV forecast for Monticello, 2008-2015 (\$ million) 
This forecast projects an NPV of ( $\$ 24.4$ million) after the project’s first eight years, reaching an annual discounted CFO of $+\$ 1.4$ million in 2015. To generate positive NPV by the initial bond maturity date of 2031, this project would have to generate an average annual discounted CFO of $+\$ 1.5$ million over the sixteen years from 2016 to 2031 , inclusive. This projection implicitly requires discounted CFO to grow at an annual growth rate of $+0.5 \%$ over that time in order to reach positive NPV and break even, which seems quite reasonable. The analysis that follows reveals that Monticello's actual performance did not meet its forecast, generating an NPV that was ( $\$ 7.7$ million) below its forecast.

\subsection{The data}

The creation of the novel dataset underlying this analysis began with a systematic effort to identify every municipal fiber project in the U.S. that received its initial financing in, or before, fiscal year 2011. The issuance of the initial debt was used as the starting date for each of these projects because that is the date from which the projects began accruing interest that must be paid regardless of when the networks began generating revenue. Tracking data through fiscal year 2019 provided at least ten years of data for all projects that are still operating and provides complete data for projects that have already terminated operations. Ending the analysis before fiscal year 2020 effectively avoids having to take the effects of the COVID-19 pandemic into account.

The principal resource for identifying municipal fiber projects is Appendix 1 of the Executive Office of the President's January 2015 report on Community-Based Broadband Solutions, which provides a comprehensive list of municipal broadband networks and identifies the technology each one uses. We augmented this list by consulting other industry and scholarly resources that list municipal fiber projects (e.g., Fiber-to-the-Home Council, 2009; Montagne 
and Chaillou, 2010; Mitchell, 2012). Review of these lists identified eighty-eight municipal fiber projects operating in fiscal year 2011.

We then examined the annual financial reports for these projects to determine how many provided separate reports for their fiber operations. ${ }^{9}$ A review of the annual financial reports identified fifteen projects operating in 2011 that provided complete reports of their fiber operations from project initiation through fiscal year 2019 or project termination. Basic data about these projects appear in Table 3, including debt information, housing units, median household income, and population density.

9 The annual reports were obtained from Bloomberg's Data Transparency feature, the Electronic Municipal Market Access Service ("EMMA") of the Securities and Exchange Commission's ("SEC's") Municipal Securities Rulemaking Board ("MSRB"), public postings to the Internet, and direct requests for information. 
Table 3:

Project and demographic data

\begin{tabular}{lccrrrrr}
\hline \hline Municipality & $\begin{array}{c}\text { Fiscal } \\
\text { year of } \\
\text { initial } \\
\text { financing }\end{array}$ & $\begin{array}{c}\text { Term of } \\
\text { initial } \\
\text { financing } \\
\text { (years) }\end{array}$ & $\begin{array}{c}\text { Amount of } \\
\text { initial } \\
\text { financing }\end{array}$ & Population & $\begin{array}{c}\text { Housing } \\
\text { units }\end{array}$ & $\begin{array}{c}\text { Median } \\
\text { household } \\
\text { income }\end{array}$ & $\begin{array}{c}\text { Population } \\
\text { per square } \\
\text { mile }\end{array}$ \\
\hline \hline Jackson, TN & 2004 & 22 & $54,300,000$ & 67,187 & 25,925 & 46,112 & 1,152 \\
Provo, UT & 2004 & 22 & $39,500,000$ & 116,616 & 34,454 & 53,864 & 2,799 \\
Windom, MN & 2004 & 20 & $12,690,000$ & 4,428 & 1,999 & 44,991 & 1,094 \\
UTOPIA, UT & 2005 & 22 & $185,000,000$ & 474.442 & 148,226 & 70,908 & 2,925 \\
Burlington, VT & 2005 & 20 & $33,500,000$ & 42,545 & 16,552 & 51,394 & 4,128 \\
Morristown, TN & 2005 & 25 & $19,500,000$ & 29,782 & 11,639 & 32,193 & 1,089 \\
Pulaski, TN & 2006 & 19 & $8,500,000$ & 7,643 & 3,189 & 31,519 & 1,018 \\
Clarksville, TN & 2007 & 25 & $41,675,000 *$ & 58.985 & 58,985 & 51,281 & 1,601 \\
Wilson, NC & 2007 & 26 & $31,800,000$ & 49,272 & 19,667 & 42,036 & 1,584 \\
Lafayette, LA & 2007 & 24 & $125,000,000$ & 126,199 & 52,267 & 51,477 & 2,274 \\
Tullahoma, TN & 2008 & 20 & $16,975,000$ & 19,852 & 8,079 & 48,770 & 847 \\
Chattanooga, TN & 2008 & 25 & $280,600,000 *$ & 264,553 & 185,000 & 48,508 & 1,391 \\
Monticello, MN & 2008 & 23 & $26,445,000$ & 13,583 & 4,984 & 65,398 & 1,552 \\
Salisbury, NC & 2009 & 21 & $35,865,000$ & 33,727 & 12,524 & 41,901 & 1,513 \\
Dunnellon, FL & 2011 & 15 & $5,500,000$ & 2,057 & 1,043 & 33,197 & 328 \\
\hline Low & 2004 & 15 & $5,500,000$ & 2,057 & 1,043 & 31,519 & 295 \\
High & 2011 & 26 & $185,000,000$ & 474,442 & 185,000 & 70,465 & 4,119 \\
Median & 2007 & 22 & $31,800,000$ & 41,500 & 16,552 & 48,770 & 1,528 \\
Mean & 2007 & 22 & $45,736,538$ & 51,865 & 38,969 & 47,570 & 1,686 \\
\hline \hline
\end{tabular}

* Project financed by electric power division.

The total amount financed and WACC are derived from the text and the coupon rates for the actual debt instruments or from the official statements that SEC rules require municipal bond issuers to provide to underwriters. ${ }^{10}$ For projects that used multiple rounds of funding to finance

10 The official statements were obtained from EMMA, Bloomberg, and public postings to the Internet. For two projects (Burlington and Dunnellon), the information was derived from the actual loan agreements, which were submitted during litigation over the default on the debt. Debt instruments that included financing for both fiber and nonfiber projects (Chattanooga, Clarksville, Morristown, and Wilson) were allocated across the projects per the infrastructure expenditures reflected in the official statements. All demographic data are taken from the U.S. Census. Regarding the multicity projects, housing units for the Utah Open Infrastructure Agency ("UTOPIA") represent the total households in all of the pledging cities, and the median household income is for the median of the pledging cities. Housing units for Chattanooga represent the total electric households served by the EPB, and median household income is for the Chattanooga Metropolitan Statistical Area. 
principal construction, the project cost represents the total capital raised by the multiple rounds. ${ }^{11}$ We made adjustments to the total amount financed so that we could compare all of the projects as if they were financed as stand-alone broadband projects. This means that the total amount financed omits any subsidies provided by state governments or the federal government. For example, the total amount financed does not include Chattanooga's stimulus funding of $\$ 111.6$ million or UTOPIA's funding of $\$ 16.2$ million. We also made adjustments where the projects were financed as smart grid projects; Chattanooga and Clarksville were financed as such, meaning that the network construction costs and corresponding debt service (i.e., capital costs) were carried by the electric power divisions of these independent authorities instead of their broadband divisions, which paid periodic use charges to the electric power divisions proportionate to their actual network usage (i.e., operating expenses). Converting these capital expenses into pay-as-you-go operating expenses allowed these projects to shift the capital risk associated with these networks to their electric power operations.

Interestingly, all of these projects are located in areas that satisfy the U.S. Census definition of urban, and only one falls below the standard used by the U.S. Department of Agricultural Economic Research Service that defines rural areas as those with a population density of less than 500 persons per square mile.

Also notable is the fact that each of these projects was an overbuild of areas already receiving broadband service from one or more private providers. None was a greenfield project designed to provide service to residences who could not previously access broadband. The presence of an incumbent led to several predictable dynamics that municipal fiber projects should anticipate. For example, any incumbent in a market that is oligopolistic or monopolistic

11 These projects include Burlington, Lafayette, Morristown, UTOPIA, and Windom. 
is generally expected to respond to entry by a new competitor by dropping price. Indeed, as noted earlier, inducing such price decreases was the goal behind projects such as Windom's. The municipal fiber projects in Monticello and Wilson regarded the incumbents' price decreases with suspicion, denouncing them as "predatory." These claims overlook the fact that, unless the prices charged are below cost, such decreases represent perhaps the primary dimension of competition on the merits.

In addition, incumbents often questioned the legality of municipal fiber efforts. For example, the incumbents in Burlington, Monticello, and Windom each contested the propriety of the means used to finance the municipal fiber projects. Although each of these challenges ultimately proved unsuccessful, the litigation delayed the projects, which caused them to forego revenue and gave the incumbents time to improve their own networks.

To assess the representativeness of this sample, we compared the basic demographic data of these projects with those of the overall universe of municipal fiber projects. The results are summarized in Table 4, and the full results are reported in Online Appendix A.

Table 4:

Project and demographic data

\begin{tabular}{lrrrr}
\hline \hline & Population & $\begin{array}{c}\text { Housing } \\
\text { units }\end{array}$ & $\begin{array}{c}\text { Median } \\
\text { household } \\
\text { income }\end{array}$ & $\begin{array}{c}\text { Population } \\
\text { per square } \\
\text { mile }\end{array}$ \\
\hline \hline Median - study cities & 41,500 & 16,096 & 47,310 & 1,452 \\
Median - all municipal fiber cities & 13,583 & 8,079 & 50,591 & 1,190 \\
\hline Mean - study cities & 97,678 & 35,290 & 47,297 & 1,512 \\
Mean - all municipal fiber cities & 49,329 & 18,392 & 50,647 & 1,430 \\
\hline \hline
\end{tabular}

As illustrated in Table 4, the projects included in this study tended to be considerably larger than the typical city supporting a municipal fiber project. This is unsurprising. Larger projects, funded by larger cities are naturally more likely to be able to support the expense of 
providing separate audited financial reports of their fiber operations, which were required to complete this study The cities within this study are also denser and have a lower median household income than the overall universe of municipal fiber projects. Two of these characteristics—-larger population size and higher population density—suggest that the sample may reflect a slight bias toward more successful projects than the overall universe of municipal fiber projects.. This is primarily driven by the reduced cost of fiber deployment in larger and more densely populated areas. The third characteristic — median household income — is roughly $6 \%$ lower in the sample than in the overall population of municipal fiber projects, which arguably creates a slight bias toward less successful projects. On balance, we expect any selection biases that may exist to be small and to largely offset one another. To the extent any overall sample bias exists, we believe it is more likely to cause the projects in the sample to perform better financially than the overall population.

\section{$5 \quad$ Results}

We now apply the NCF and NPV analysis described above to these fifteen projects. Full details are available in Online Appendix B.

\subsection{Actual performance: Adjusted nominal cash flow ("ANCF")}

The results of our cumulative ANCF analysis are summarized in Table 5. The second column assesses short-run solvency by examining the lowest cumulative ANCF during each project's life. If this number is negative, the project has not generated sufficient cash flow to cover its costs in at least one year and has required infusions of additional cash from outside sources to remain solvent. 
The other columns assess long-run solvency. The third column reports each project's cumulative ANCF as of 2019 to determine if it is currently running a deficit or surplus. The fourth column reports the ANCF each project has generated over the past three fiscal years (2017, 2018, and 2019). The fifth column uses the recent returns reported in the fourth column to project how many years each project would need to make up for any deficits reported in the third column. The sixth column, which reports the number of years until the maturity date of the initial debt, can be compared with the fifth column to determine whether a project is on track to repay its debt.

Table 5:

Cumulative ANCF analysis

\begin{tabular}{lccccc}
\hline \hline & $\begin{array}{c}\text { Lowest } \\
\text { cumulative } \\
\text { PNCF through }\end{array}$ & $\begin{array}{c}\text { Cumulative } \\
\text { ANCF as of } \\
2019\end{array}$ & $\begin{array}{c}\text { Average } \\
\text { annual ANCF, } \\
2017-19\end{array}$ & $\begin{array}{c}\text { Years to } \\
\text { break even } \\
\text { at 2017-19 } \\
\text { ANCF rates }\end{array}$ & $\begin{array}{c}\text { Years until } \\
\text { initial debt } \\
\text { maturity }\end{array}$ \\
\hline \hline Chattanooga, TN & $(24,164,960)$ & $68,578,465$ & $22,742,128$ & 0 & 15 \\
Wilson, NC & $(7,544,971)$ & $(4,672,373)$ & 731,218 & 6 & 14 \\
\hline Clarksville, TN & $(28,536,619)$ & $(23,218,789)$ & $1,275,398$ & 18 & 14 \\
Lafayette, LA & $(46,769,435)$ & $(44,625,525)$ & 714,637 & 62 & 13 \\
Windom, MN & $(2,376,777)$ & $(1,988,432)$ & 19,761 & 101 & 6 \\
Jackson, TN & $(6,857,654)$ & $1,561,170$ & $(1,002,459)$ & never & 7 \\
Tullahoma, TN & $(194,672)$ & $(194,672)$ & $(533,779)$ & never & 9 \\
Pulaski, TN & $(3,317,057)$ & $(3,317,057)$ & $(453,755)$ & never & 6 \\
Morristown, TN & $(14,579,821)$ & $(14,579,821)$ & $(874,204)$ & never & 11 \\
Monticello, MN & $(16,732,246)$ & $(16,732,246)$ & $(1,768,214)$ & never & 12 \\
Salisbury, NC & $(24,455,847)$ & $(24,455,847)$ & $(3,209,227)$ & never & 10 \\
UTOPIA, UT & $(159,270,166)$ & $(159,270,166)$ & $(14,431,235)$ & never & 8 \\
Dunnellon, FL & $(8,643,210)$ & $(8,643,210)$ & n/a & never & 7 \\
Provo, UT & $(11,126,580)$ & $(9,765,585)$ & n/a & never & 7 \\
Burlington, VT & $(32,059,526)$ & $(32,059,526)$ & n/a & never & 9 \\
\hline \hline
\end{tabular}

In terms of actual performance, none of the fifteen projects satisfied the short-run test for viability based on ANCF by generating cumulative ANCF surpluses every year of their 
operation. That means that all of the projects either required infusions of cash from outside sources or debt relief through refinancing. The size of the peak cumulative ANCF deficits ranged from (\$0.2 million) to (\$159.3 million), with the median peak deficit running (\$14.6 million), and the average peak deficit running (\$25.80 million). To date, Tullahoma’s short-run deficit is fairly small, although recent returns suggest that it will widen unless its financial performance substantially improves.

In terms of long-run viability, only two projects (13\%) have generated sufficient cumulative ANCF to be on track to cover their initial debt before it is scheduled to mature: Chattanooga has already broken even, and Wilson would break even in six years if it is able to maintain the level of performance it has achieved over the past three years, which would be well before the maturity date of its initial debt in fourteen years. Of the remaining thirteen projects (87\%), only three generated positive cumulative ANCF over the last three fiscal years (Clarksville, Lafayette, and Wilson), although at too low a level to break even by the maturity date of their initial debt, although Clarksville is close. The remaining ten projects (67\%) either generated negative ANCF over the last three fiscal years or had already been sold at a significant loss. Note that Jackson ran a small cumulative ANCF surplus through 2019, but its negative ANCF over the past three fiscal years indicate that the surplus will turn into a deficit in roughly a year and a half unless it substantially improves the fiscal performance of its operations.

Somewhat surprisingly, ten of the fifteen projects $(67 \%)$ have either generated negative cumulative ANCF over the past three fiscal years $(2017,2018$, and 2019) or have already ceased operations at a loss. Projects that generate negative cumulative and annual ANCF have no chance of repaying their debt and, even worse, risk sinking further into debt with every year they continue to operate. 


\subsection{Theoretical performance: Net present value ("NPV") of discounted cash flow from operations ("CFO")}

The NPV analysis of these projects' discounted CFO yields slightly different results, which are reported in Table 6 . The second column reports the project financing, adjusted as described in Section 4.1.2 above. The third column reports the cumulative discounted CFO from the initiation of the project through fiscal year 2019. The fourth column reports the projects' NPV, calculated by subtracting the cumulative discounted CFO (third column) from the initial project financing (second column). The fifth column reports the average annual discounted CFO each project has generated over the past three fiscal years $(2017,2018$, and 2019). The sixth

column uses the recent returns (fifth column) to project how many years each project would need to make up for any deficits (fourth column). The seventh column reports the number of years until the maturity date of the initial debt, which can be compared to the sixth column to determine whether a project is on track to repay its debt. 
Table 6:

Cumulative lifetime discounted CFO and NPV analysis

\begin{tabular}{|c|c|c|c|c|c|c|}
\hline Project & $\begin{array}{c}\text { Initial } \\
\text { project } \\
\text { financing }\end{array}$ & $\begin{array}{c}\text { Cumulative } \\
\text { discounted } \\
\text { CFO as of } \\
2019\end{array}$ & $\begin{array}{c}\text { NPV as of } \\
2019\end{array}$ & $\begin{array}{c}\begin{array}{c}\text { Average } \\
\text { annual }\end{array} \\
\text { discounted } \\
\text { CFO, 2017- } \\
19 \\
\end{array}$ & $\begin{array}{c}\text { Estimated } \\
\text { years to } \\
\text { break even } \\
\text { as of } 2019\end{array}$ & $\begin{array}{c}\text { Years until } \\
\text { initial debt } \\
\text { maturity }\end{array}$ \\
\hline Jackson, TN & $54,300,000$ & $76,617,231$ & $22,317,231$ & $5,687,460$ & 0 & 7 \\
\hline Chattanooga, TN & $280,600,000$ & $228,523,244$ & $(52,076,756)$ & $27,952,186$ & 2 & 15 \\
\hline Wilson, NC & $29,190,000$ & $22,234,399$ & $(6,955,601)$ & $2,756,778$ & 3 & 14 \\
\hline Morristown, TN & $19,500,000$ & $12,604,555$ & $(6,895,445)$ & $1,597,193$ & 4 & 11 \\
\hline Lafayette, LA & $125,000,000$ & $71,568,919$ & $(53,431,081)$ & $10,402,161$ & 5 & 13 \\
\hline Tullahoma, TN & $16,975,000$ & $10,473,169$ & $(6,501,831)$ & $1,079,637$ & 6 & 9 \\
\hline Clarksville, TN & $41,675,000$ & $6,145,754$ & $(35,529,246)$ & $2,601,301$ & 14 & 14 \\
\hline Pulaski, TN & $8,500,000$ & $3,999,274$ & $(4,500,726)$ & 383,430 & 12 & 6 \\
\hline Windom, MN & $12,690,000$ & $4,382,488$ & $(8,307,512)$ & 418,371 & 20 & 6 \\
\hline Salisbury, NC & $35,865,000$ & $(795,753)$ & $(36,660,753)$ & 103,269 & 355 & 10 \\
\hline Monticello, MN & $26,445,000$ & $(5,895,812)$ & $(32,340,812)$ & 1,965 & 16,461 & 12 \\
\hline UTOPIA, UT & $85,000,000$ & $(17,538,964)$ & $(102,538,964)$ & $(59,648)$ & never & 8 \\
\hline Dunnellon, FL & $7,350,000$ & $(3,408,484)$ & $(10,758,484)$ & $\mathrm{n} / \mathrm{a}$ & $\mathrm{n} / \mathrm{a}$ & 7 \\
\hline Burlington, VT & $33,500,000$ & $3,399,230$ & $(30,100,770)$ & $\mathrm{n} / \mathrm{a}$ & $\mathrm{n} / \mathrm{a}$ & 9 \\
\hline Provo, UT & $39,500,000$ & $2,118,521$ & $(37,381,479)$ & $\mathrm{n} / \mathrm{a}$ & $\mathrm{n} / \mathrm{a}$ & 7 \\
\hline
\end{tabular}

* Project financed entirely by the electric power division and/or grants.

More than half of the fifteen projects (53\%) are not on track to generate a positive NPV, and thus breakeven, by the maturity date of their initial debt financing. Of these, three projects (20\%) have already ceased operations and thus no longer have any opportunity to make up their deficits. One project (7\%) generated negative $\mathrm{CFO}$ and fell even further behind in recent years (UTOPIA). The remaining seven projects (47\%) generated positive discounted CFO but will have to improve their operations substantially in order to break-even.

Of the seven projects (47\%) that are on track to break-even under NPV, one project $(7 \%)$, Jackson, has already generated positive NPV and continued to generate positive discounted CFO over the past three fiscal years. The remaining six projects (40\%) should generate positive NPV well before the maturity dates of their initial debt. Notably, two of the projects with the largest 
deficits as of 2019, Lafayette at (\$53.4 million) and Chattanooga at (\$52.1 million), generated sufficient discounted CFO in recent years to put them on track to break even in just a few years.

\subsection{Synthesis of the three approaches to analyzing viability}

Combining the three approaches to analyzing cash flow provides a robust assessment of these projects' viability, with the results summarized in Table 7.

Table 7:

Synthesis of the two approaches to analyzing cash flow

\begin{tabular}{|c|c|c|c|}
\hline Project & $\begin{array}{l}\text { Actual performance: } \\
\text { short-run viability }\end{array}$ & $\begin{array}{l}\text { Actual performance: } \\
\text { long-run viability }\end{array}$ & $\begin{array}{c}\text { Theoretical } \\
\text { performance: } \\
\text { long-run viability }\end{array}$ \\
\hline Chattanooga, TN & & $\mathrm{X}$ & $\mathrm{X}$ \\
\hline Wilson, NC & & $\mathrm{X}$ & $\mathrm{X}$ \\
\hline Clarksville, TN & & & $\mathrm{X}$ \\
\hline Jackson, TN & & & $X$ \\
\hline Lafayette, LA & & & $\mathrm{X}$ \\
\hline Morristown, TN & & & $\mathrm{X}$ \\
\hline Tullahoma, TN & & & $\mathrm{X}$ \\
\hline \multicolumn{4}{|l|}{ Pulaski, TN } \\
\hline \multicolumn{4}{|l|}{ Salisbury, NC } \\
\hline \multicolumn{4}{|l|}{ UTOPIA, UT } \\
\hline \multicolumn{4}{|l|}{ Windom, MN } \\
\hline \multicolumn{4}{|l|}{ Monticello, MN } \\
\hline \multicolumn{4}{|l|}{ Burlington, VT } \\
\hline \multicolumn{4}{|l|}{ Dunnellon, FL } \\
\hline Provo, UT & & & \\
\hline
\end{tabular}

None of the fifteen projects, when corrected for changes in financing and cash infusions from other sources, satisfied the test for actual short-run viability. In terms of long-run viability, only two projects (14\%) satisfied the tests based on both actual and theoretical performance: Chattanooga and Wilson. Five additional projects (33\%) failed the long-run test based on actual performance but passed the test based on theoretical performance. Eight projects (53\%) failed the tests of long-run viability based on both actual and theoretical performance. 


\subsection{Internal details of project performance}

Closer analysis of the internal details of these fifteen projects' financial performance provides additional insights. Table 8 provides an overview of which projects required external funding, used refinancing to defer aspects of their debt service, saw a significant downgrade to their bond rating, defaulted on their debt, or were sold to other entities at a loss.

Table 8:

Internal details of project performance

\begin{tabular}{|c|c|c|c|c|c|c|c|c|c|}
\hline \multirow[b]{2}{*}{ Project } & \multicolumn{2}{|c|}{ External funding } & \multirow{2}{*}{$\begin{array}{c}\text { Backing } \\
\text { with } \\
\text { taxing } \\
\text { power }\end{array}$} & \multicolumn{2}{|c|}{ Refinance deferrals } & \multirow{2}{*}{$\begin{array}{l}\text { Negative } \\
\text { statements } \\
\text { in annual } \\
\text { report }\end{array}$} & \multirow{2}{*}{$\begin{array}{c}\text { Bond } \\
\text { rating } \\
\text { downgrade }\end{array}$} & \multirow[b]{2}{*}{ Default } & \multirow[b]{2}{*}{ Disposal } \\
\hline & $\begin{array}{c}\text { Tax } \\
\text { dollars }\end{array}$ & $\begin{array}{l}\text { Interfund } \\
\text { loans }\end{array}$ & & $\begin{array}{l}\text { Principal } \\
\text { repayment }\end{array}$ & $\begin{array}{c}\text { Maturity } \\
\text { date }\end{array}$ & & & & \\
\hline Jackson, TN & & $\mathrm{X}$ & & $\mathrm{X}$ & $\mathrm{X}$ & & $\mathrm{X}$ & & \\
\hline Provo, UT & $\mathrm{X}$ & $\mathrm{X}$ & & & & & $\mathrm{X}$ & & $\mathrm{X}$ \\
\hline Windom, MN & & $\mathrm{X}$ & & & $\mathrm{X}$ & & & & \\
\hline UTOPIA, UT & $\mathrm{X}$ & & $\mathrm{X}$ & & $\mathrm{X}$ & & & & \\
\hline Burlington, VT & $\mathrm{X}$ & $\mathrm{X}$ & & $\mathrm{X}$ & & $\mathrm{X}$ & $\mathrm{X}$ & $\mathrm{X}$ & $\mathrm{X}$ \\
\hline Morristown, TN & & $\mathrm{X}$ & $\mathrm{X}$ & $\mathrm{X}$ & $\mathrm{X}$ & & $\mathrm{X}$ & & \\
\hline Pulaski, TN & & & $\mathrm{X}$ & & & & & & \\
\hline Clarksville, TN & & $\mathrm{X}$ & & & & $\mathrm{X}$ & & & \\
\hline Wilson, NC & & $\mathrm{X}$ & & & & & & & \\
\hline Lafayette, LA & & $\mathrm{X}$ & & & & $\mathrm{X}$ & & & \\
\hline Tullahoma, TN & & & $\mathrm{X}$ & & & $\mathrm{X}$ & & & \\
\hline Chattanooga, TN & & $\mathrm{X}$ & & & & & & & \\
\hline Monticello, MN & $\mathrm{X}$ & $\mathrm{X}$ & & & & $\mathrm{X}$ & & $\mathrm{X}$ & \\
\hline Salisbury, NC & $\mathrm{X}$ & $\mathrm{X}$ & & $\mathrm{X}$ & & $\mathrm{X}$ & $\mathrm{X}$ & & \\
\hline Dunnellon, FL & $\mathrm{X}$ & & $\mathrm{X}$ & & & & & $\mathrm{X}$ & $\mathrm{X}$ \\
\hline
\end{tabular}

Despite the fact that all fifteen projects were supposed to be self-sustaining, fourteen projects $(93 \%)$ received additional funds from outside sources, with the sole exceptions being Tullahoma and Pulaski. This additional funding took on different forms, with some cities relying on more than one source. Six projects (40\%) received contributions supported by tax dollars (Burlington, Dunnellon, Monticello, Provo, Salisbury, and UTOPIA). Eleven projects (69\%) 
received interfund loans from other municipal units. Many projects borrowed significant amounts, with the peak of these loans averaging $37 \%$ of the initial debt financing.

Ten projects $(67 \%)$ declined to back their debt with the cities' taxing power and full faith and credit. Of these, three projects (20\%) nonetheless provided support for the municipal fiber projects out of their general funds despite the specific language in the debt instrument protecting these cities from having to do so (Burlington, Monticello, and Salisbury).

Five projects (33\%) used refinancing to mitigate their debt obligations. Four projects (27\%) deferred the date when repayment of principal was to begin (Burlington, Jackson, Morristown, Salisbury). Four projects (27\%) extended the maturity date of the debt (Jackson, Morristown, UTOPIA, and Windom).

Six cities (40\%) included negative statements about their fiber operations in their annual reports, although all but two of them (Lafayette and Salisbury) had addressed those issues by 2019. Six projects (40\%) saw significant downgrades to their bond ratings, although one has recovered (Burlington). Three projects (20\%) have defaulted on their debt (Burlington, Dunnellon, and Monticello). Of these, two projects (13\%) stopped servicing their debt just before principal repayments were supposed to begin (Burlington and Monticello). The remaining project (7\%) made the necessary payments until it disposed of the project during its fourth year of operations, when it settled its debt for less than its full value (Dunnellon). Three projects (20\%) sold their operations at significant losses (Burlington, Dunnellon, and Provo).

\section{Comparing the Forecast vs. Actual Performance for Three Projects}

The wide variability in outcomes invites further inquiry into what factors drive success and failure. One approach to determining why municipal fiber projects succeed or fail is to 
compare a project's financial forecast with its actual performance. Three municipal fiber projects included pro forma projections of their financial performance as appendices to their official bond statements: Lafayette, Monticello, and Windom. Their inclusion allows us to compare these projects forecast vs. actual financial performance under both of our measures.

\subsection{Actual performance: Adjusted nominal cash flow ("ANCF")}

A comparison of the projected versus actual financial performance for these three projects in terms of NCF appears in Table 9. 
Table 9:

Forecast vs. actual annual and cumulative discounted NCF for Lafayette, Monticello, and Windom

\begin{tabular}{|c|c|c|c|c|c|c|c|c|c|c|}
\hline Lafayette & 2007 & 2008 & 2009 & 2010 & 2011 & 2012 & 2013 & 2014 & 2015 & 2016 \\
\hline Forecast annual NCF & $114,249,291$ & $(54,931,139)$ & $(28,870,820)$ & $(21,994,851)$ & $6,626,788$ & $10,427,865$ & $12,836,428$ & $11,974,637$ & $15,331,703$ & $19,016,684$ \\
\hline Actual annual ANCF & $112,328,272$ & $(36,032,608)$ & $(50,086,859)$ & $(24,943,506)$ & $(17,050,668)$ & $4,324,114$ & $(5,836,755)$ & $(3,338,611)$ & $(4,621,158)$ & $(513,137)$ \\
\hline Difference & $(1,921,019)$ & $18,898,531$ & $(21,216,039)$ & $(2,948,655)$ & $(23,677,456)$ & $(6,103,751)$ & $(18,673,183)$ & $(15,313,248)$ & $(19,952,861)$ & $(19,529,821)$ \\
\hline Forecast cumulative NCF & $114,249,291$ & $59,318,152$ & $30,447,332$ & $8,452,481$ & $15,079,269$ & $25,507,134$ & $38,343,562$ & $50,318,199$ & $65,649,902$ & $84,666,586$ \\
\hline Actual cumulative ANCF & $112,328,272$ & $76,295,664$ & $26,208,805$ & $1,265,299$ & $(15,785,369)$ & $(11,461,255)$ & $(17,298,010)$ & $(20,636,621)$ & $(25,257,779)$ & $(25,770,916)$ \\
\hline Difference & $(1,921,019)$ & $16,977,512$ & $(4,238,527)$ & $(7,187,182)$ & $(30,864,638)$ & $(36,968,389)$ & $(55,641,572)$ & $(70,954,820)$ & $(90,907,681)$ & $(110,437,502)$ \\
\hline Monticello & 2008 & 2009 & 2010 & 2011 & 2012 & 2013 & 2014 & 2015 & & \\
\hline Forecast annual NCF & $13,663,984$ & $(5,592,722)$ & $(2,913,510)$ & $(289,462)$ & 254,342 & 250,576 & $1,264,026$ & $1,429,721$ & & \\
\hline Actual annual ANCF & $23,178,435$ & $(7,601,472)$ & $(9,436,684)$ & $(5,442,873)$ & $(2,817,900)$ & $(3,061,050)$ & $(10,481,375)$ & $(2,298,306)$ & & \\
\hline Difference & $9,514,451$ & $(2,008,750)$ & $(6,523,174)$ & $(5,153,411)$ & $(3,072,242)$ & $(3,311,626)$ & $(11,745,401)$ & $(3,728,027)$ & & \\
\hline Forecast cumulative NCF & $13,663,984$ & $8,071,262$ & $5,157,752$ & $4,868,290$ & $5,122,632$ & $5,373,208$ & $6,637,234$ & $8,066,955$ & & \\
\hline Actual cumulative ANCF & $23,178,435$ & $15,576,963$ & $6,140,279$ & 697,406 & $(2,120,494)$ & $(5,181,544)$ & $(15,662,919)$ & $(17,961,225)$ & & \\
\hline Difference & $9,514,451$ & $7,505,701$ & 982,527 & $(4,170,884)$ & $(7,243,126)$ & $(10,554,752)$ & $(22,300,153)$ & $(26,028,180)$ & & \\
\hline Windom & 2004 & 2005 & 2006 & 2007 & 2008 & 2009 & 2010 & 2011 & & \\
\hline Forecast annual NCF & $(140,677)$ & 187,352 & $(75,365)$ & 39,923 & 111,902 & 136,229 & 165,613 & 229,245 & & \\
\hline Actual annual ANCF & $(337,385)$ & $(77,308)$ & $(663,913)$ & $1,025,149$ & $(349,122)$ & $(1,469,191)$ & $(22,305)$ & $(282,702)$ & & \\
\hline Difference & $(196,708)$ & $(264,660)$ & $(588,548)$ & 985,226 & $(461,024)$ & $(1,605,420)$ & $(187,918)$ & $(511,947)$ & & \\
\hline Forecast cumulative NCF & $(140,677)$ & 46,675 & $(28,690)$ & 11,233 & 123,135 & 259,364 & 424,977 & 654,222 & & \\
\hline Actual cumulative ANCF & $(337,385)$ & $(414,693)$ & $(1,078,606)$ & $(53,457)$ & $(402,579)$ & $(1,871,770)$ & $(1,894,075)$ & $(2,176,777)$ & & \\
\hline Difference & $(196,708)$ & $(461,368)$ & $(1,049,916)$ & $(64,690)$ & $(525,714)$ & $(2,131,134)$ & $(2,319,052)$ & $(2,830,999)$ & & \\
\hline
\end{tabular}


All three of these projects' actual performance fell far short of their forecasts. While Lafayette was forecast to begin running NCF surpluses in its fifth year, it actually ran ANCF deficits for all ten years covered by the forecasts. The predicted $\$ 84.7$ million cumulative NCF surplus was actually a (\$25.8 million) ANCF deficit, for a shortfall of (\$110.4 million).

Monticello was also forecast to begin running NCF surpluses in its fifth year, while it actually ran ANCF deficits for all eight years covered by the forecast despite the fact that it defaulted on its debt and stopped making debt payments in its fifth year. The forecasted $\$ 8.1$ million cumulative NCF surplus was actually a (\$18.0 million) deficit, for a shortfall of ( $\$ 26.0$ million). To get a sense of the magnitude of this shortfall, for both Lafayette and Monticello, the cumulative deficit was roughly the same size as the initial bond debt borrowed to finance the entire project.

Windom underperformed but to a lesser extent than the other two projects. Forecasts projected that Windom would begin running NCF surpluses in year four, and it actually generated a significantly greater ANCF surpluses in that year before reverting to negative ANCF. The projected $\$ 229$ thousand cumulative NCF surplus was actually a (\$283 thousand) cumulative ANCF deficit, for a cumulative shortfall of ( $\$ 512$ thousand). While still negative, this shortfall is much smaller than the $\$ 12.7$ million needed to finance the overall project.

\subsection{Theoretical performance: Net present value ("NPV") of discounted cash flow from operations ("CFO")}

The availability of CFO forecasts for three projects allows us to focus more narrowly on their operational performance as compared to forecasts. Both forecast and actual CFO are presented in Table 10. 
Table 10:

Forecast vs. actual annual and cumulative CFO for Lafayette, Monticello, and Windom

\begin{tabular}{|c|c|c|c|c|c|c|c|c|c|c|}
\hline Lafayette & 2007 & 2008 & 2009 & 2010 & 2011 & 2012 & 2013 & 2014 & 2015 & 2016 \\
\hline Forecast annual $\mathrm{CFO}$ & 887,757 & $(2,229,287)$ & $(1,562,305)$ & $10,612,738$ & $19,157,937$ & $22,688,720$ & $24,594,879$ & $27,084,681$ & $27,916,573$ & $30,132,584$ \\
\hline Actual annual CFO & $(32,232)$ & $(1,836,668)$ & $(3,018,092)$ & $(462,491)$ & $2,256,273$ & $6,927,545$ & $10,083,645$ & $14,093,749$ & $15,140,084$ & $15,727,652$ \\
\hline Difference & $(919,989)$ & 392,619 & $(1,455,787)$ & $(11,075,229)$ & $(16,901,664)$ & $(15,761,175)$ & $(14,511,234)$ & $(12,990,932)$ & $(12,776,489)$ & $(14,404,932)$ \\
\hline Forecast cumulative $\mathrm{CFO}$ & 887,757 & $(1,341,530)$ & $(2,903,835)$ & $7,708,903$ & $26,866,840$ & $49,555,560$ & $74,150,439$ & $101,235,120$ & $129,151,693$ & $159,284,277$ \\
\hline Actual cumulative CFO & $(32,232)$ & $(1,868,900)$ & $(4,886,992)$ & $(5,349,483)$ & $(3,093,210)$ & $3,834,335$ & $13,917,980$ & $28,011,729$ & $43,151,813$ & $58,879,465$ \\
\hline Difference & $(919,989)$ & $(527,370)$ & $(1,983,157)$ & $(13,058,386)$ & $(29,960,050)$ & $(45,721,225)$ & $(60,232,459)$ & $(73,223,391)$ & $(85,999,880)$ & $(100,404,812)$ \\
\hline Monticello & 2008 & 2009 & 2010 & 2011 & 2012 & 2013 & 2014 & 2015 & & \\
\hline Forecast annual CFO & $(468,885)$ & $(2,016,902)$ & $(549,331)$ & 436,569 & 879,246 & $1,586,317$ & $1,918,825$ & $2,213,870$ & & \\
\hline Actual annual CFO & $(78,776)$ & $(293,576)$ & $(1,560,790)$ & $(2,085,220)$ & $(1,052,562)$ & $(984,045)$ & $(851,502)$ & $(189,943)$ & & \\
\hline Difference & 390,109 & $1,723,326$ & $(1,011,459)$ & $(2,521,789)$ & $(1,931,808)$ & $(2,570,362)$ & $(2,770,327)$ & $(2,403,813)$ & & \\
\hline Forecast cumulative $\mathrm{CFO}$ & $(468,885)$ & $(2,485,787)$ & $(3,035,118)$ & $(2,598,549)$ & $(1,719,303)$ & $(132,986)$ & $1,785,839$ & $3,999,709$ & & \\
\hline Actual cumulative $\mathrm{CFO}$ & $(78,776)$ & $(372,352)$ & $(1,933,142)$ & $(4,018,362)$ & $(5,070,924)$ & $(6,054,969)$ & $(6,906,471)$ & $(7,096,414)$ & & \\
\hline Difference & 390,109 & $2,113,435$ & $1,101,976$ & $(1,419,813)$ & $(3,351,621)$ & $(5,921,983)$ & $(8,692,310)$ & $(11,096,123)$ & & \\
\hline Windom & 2004 & 2005 & 2006 & 2007 & 2008 & 2009 & 2010 & 2011 & & \\
\hline Forecast annual $\mathrm{CFO}$ & $(215,850)$ & $(262,162)$ & $(49,940)$ & 63,623 & 162,327 & 234,929 & 316,038 & 417,945 & & \\
\hline Actual annual CFO & $(509,228)$ & $(1,031,619)$ & 194,478 & 519,223 & 399,752 & 615,549 & 596,956 & 599,487 & & \\
\hline Difference & $(293,378)$ & $(769,457)$ & 244,418 & 455,600 & 237,425 & 380,620 & 280,918 & 181,542 & & \\
\hline Forecast cumulative $\mathrm{CFO}$ & $(215,850)$ & $(478,012)$ & $(527,952)$ & $(464,329)$ & $(302,002)$ & $(67,073)$ & 248,965 & 666,910 & & \\
\hline Actual cumulative $\mathrm{CFO}$ & $(509,228)$ & $(1,540,847)$ & $(1,346,369)$ & $(827,146)$ & $(427,394)$ & 188,155 & 785,111 & $1,384,598$ & & \\
\hline Difference & $(293,378)$ & $(1,062,835)$ & $(818,417)$ & $(362,817)$ & $(125,392)$ & 255,228 & 536,146 & 717,688 & & \\
\hline
\end{tabular}


Again, Lafayette and Monticello significantly underperformed expectations. Lafayette began producing CFO surpluses in year five, only one year later than forecasted, but the size of these surpluses in years five to ten fell far enough below forecasts that the cumulative deficit reached (\$100.4 million).

Regarding Monticello, despite being forecast to begin generating positive operational cash flow in its fourth year, Monticello failed to generate positive CFO throughout the eight year forecast period. The total shortfall in cumulative CFO reached ( $\$ 11.1$ million).

Windom provides a comparative bright spot, generating positive CFO in its third year, one year ahead of schedule. The cumulative CFO over Windom's first eight years of operation exceeded forecasts by $\$ 717$ thousand. While better than Lafayette's or Monticello's, this level of performance still lagged behind the pace needed to cover Windom's debt, as indicated in Table 6.

\subsection{Analyzing the determinants of viability}

The variability of these results invite further analysis of which aspects were primarily responsible for the differences in these projects' financial performance. Table 11 presents a summary of nine potential factors. 
Table 11:

Projected versus actual performance for Lafayette, Monticello, and Windom

\begin{tabular}{|c|c|c|c|c|}
\hline & & $\begin{array}{r}\text { Lafayette } \\
2007-2016\end{array}$ & $\begin{array}{l}\text { Monticello } \\
2008-2015\end{array}$ & $\begin{array}{r}\text { Windom } \\
2004-2011 \\
\end{array}$ \\
\hline \multirow{4}{*}{$\begin{array}{l}\text { Customers } \\
\text { in the final } \\
\text { year of the } \\
\text { forecast } \\
\text { period* }\end{array}$} & Projected & 29,555 & 2,543 & 1,188 \\
\hline & Actual & 17,686 & 1,487 & 1,073 \\
\hline & Difference & $(11,869)$ & $(1,056)$ & (115) \\
\hline & Pct. difference & $-40 \%$ & $-42 \%$ & $-10 \%$ \\
\hline \multirow{4}{*}{$\begin{array}{l}\text { Operating } \\
\text { revenue }\end{array}$} & Projected & $367,113,147$ & $37,699,878$ & $12,814,000$ \\
\hline & Actual & $186,314,498$ & $10,567,972$ & $11,329,437$ \\
\hline & Difference & $(180,798,649)$ & $(27,131,906)$ & $(1,484,563)$ \\
\hline & Pct. difference & $-49 \%$ & $-72 \%$ & $-12 \%$ \\
\hline \multirow{4}{*}{$\begin{array}{l}\text { Average } \\
\text { revenue } \\
\text { per user } \\
\text { (ARPU) }\end{array}$} & Projected & 12,421 & 14,825 & 10,786 \\
\hline & Actual & 10,535 & 7,107 & 10,559 \\
\hline & Difference & $(1,887)$ & $(7,718)$ & $(228)$ \\
\hline & Pct. difference & $-15 \%$ & $-52 \%$ & $-2 \%$ \\
\hline \multirow{4}{*}{$\begin{array}{l}\text { Operating } \\
\text { expense }\end{array}$} & Projected & $(207,828,869)$ & $(33,114,151)$ & $(11,300,991)$ \\
\hline & Actual & $(94,216,489)$ & $(19,471,147)$ & $(14,606,820)$ \\
\hline & Difference & $113,612,380$ & $13,643,004$ & $(3,305,829)$ \\
\hline & Pct. difference & $-55 \%$ & $-41 \%$ & $+29 \%$ \\
\hline \multirow{4}{*}{$\begin{array}{l}\text { Operating } \\
\text { expenses / } \\
\text { operating } \\
\text { revenue }\end{array}$} & Projected & $-57 \%$ & $-88 \%$ & $-88 \%$ \\
\hline & Actual & $-51 \%$ & $-184 \%$ & $-129 \%$ \\
\hline & Difference & $6 \%$ & $-96 \%$ & $-41 \%$ \\
\hline & Pct. difference & $11 \%$ & $-110 \%$ & $-46 \%$ \\
\hline \multirow{4}{*}{$\begin{array}{l}\text { Operating } \\
\text { income }\end{array}$} & Projected & $159,284,278$ & $4,585,727$ & $1,177,349$ \\
\hline & Actual & $(32,509,994)$ & $(8,903,175)$ & $(3,277,383)$ \\
\hline & Difference & $(191,794,272)$ & $(13,488,902)$ & $(4,454,732)$ \\
\hline & Pct. difference & $-120 \%$ & $-294 \%$ & $-378 \%$ \\
\hline \multirow{4}{*}{$\begin{array}{l}\text { Additions } \\
\text { to plant }\end{array}$} & Projected & $(125,998,195)$ & $(20,356,614)$ & $(8,376,101)$ \\
\hline & Actual & $(127,387,523)$ & $(15,178,684)$ & $(9,481,853)$ \\
\hline & Difference & $(1,389,328)$ & $5,177,930$ & $(1,105,752)$ \\
\hline & Pct. difference & $+1 \%$ & $-25 \%$ & $+13 \%$ \\
\hline \multirow{4}{*}{$\mathrm{CFO}$} & Projected & $155,182,418$ & $3,999,509$ & 666,910 \\
\hline & Actual & $28,011,729$ & $(7,095,414)$ & $1,384,598$ \\
\hline & Difference & $(127,170,689)$ & $(11,094,923)$ & 717,688 \\
\hline & Pct. difference & $-82 \%$ & $-277 \%$ & $+108 \%$ \\
\hline \multirow{4}{*}{$\begin{array}{l}\text { Debt } \\
\text { service }\end{array}$} & Projected & $(62,777,862)$ & $(12,331,000)$ & $(4,609,570)$ \\
\hline & Actual & $(53,849,276)$ & $(13,766,869)$ & $(4,607,735)$ \\
\hline & Difference & $8,928,586$ & $(1,435,869)$ & 1,835 \\
\hline & Pct. difference & $-14 \%$ & $+12 \%$ & $+0 \%$ \\
\hline
\end{tabular}

* Includes only data customers for Monticello and Windom; includes combined data, telephone, and cable television customers for Lafayette 
The primary driver of Windom's somewhat more positive results appears to be its relative success in acquiring customers. Its customer total in 2011 fell only $-10 \%$ short of forecasts, which was much smaller than Lafayette's $-40 \%$ or Monticello's $-42 \%$ shortfalls. As a result, Windom's revenue fell short of forecasts by only $-12 \%$, compared to $-49 \%$ for Lafayette and $-72 \%$ for Monticello. These differences in shortfall clearly resulted from the number of customers, rather than the amount of revenue generated from each customer, as Windom and Lafayette generated similar ARPU of roughly $+\$ 10,500$, with Monticello only slightly behind.

Operating efficiency appears to have played a less significant a role. The ratio of Windom's operating expenses to operating revenue underperformed expectations by $-46 \%$. Similarly, Monticello's operating efficiency was $-110 \%$ versus expectations. This did not prevent either Windom or Monticello from outperforming Lafayette in terms of CFO, despite Lafayette's $+11 \%$ improvement in operating efficiency as compared to expectations.

The role of capital expenses is similarly unclear. The fact that Windom's additions to plant exceeded forecasts by $+13 \%$ did not prevent it from meeting expectations in terms of CFO. Conversely, Monticello's $-25 \%$ lower expenditures on additions to plant compared with forecasts did not lift its performance above Windom's. Lafayette's capital expenditures were right in line with forecasts, exceeding them by a mere $+1 \%$.

\section{Conclusion}

To date, debates over municipal fiber have been long on rhetoric and short on systematic empirical assessment of financial performance. And to the extent scholars have offered any assessment of municipal fiber projects, they have stemmed from cherry-picked case studies and analysis of inappropriate financial metrics. This analysis fills the void and provides cities 
weighing whether to initiate a municipal fiber project with hard data based on the actual performance of existing municipal fiber projects to inform their decisions whether to proceed.

An examination of the actual performance of the fifteen projects for which complete data since 2011 are available reveals that none of them satisfied the standard test of short-run financial viability, which required them to receive infusions of additional cash from outside sources or obtain some form of debt relief. In terms of long-run viability, again measured by actual performance, thirteen projects (87\%) generated insufficient ANCF to put them on track to repay their debt by the date their initial debt is scheduled to mature. Moreover, eleven projects (73\%) have either already defaulted or generated negative cumulative ANCF over the past three fiscal years, which leaves them poorly positioned unless they substantially improve their operations. An assessment of theoretical, best-case performance based on the NPV of CFO reveals that, even if these projects had achieved optimal performance for capital expenditures and debt service, the majority of the projects (53\%) generated insufficient discounted CFO to cover their project costs.

Closer analysis of the projects in our study reveals further problems. Although all fifteen were expected to be self-sustaining, thirteen $(87 \%)$ received further infusions of cash. Six of the projects (40\%) received such infusions from general revenue even though three of those (20\%) declined to back their initial debt with their general taxing power. Five projects $(33 \%)$ used refinancing to defer the due date of principal repayment or to extend the maturity date of the debt. Six projects (40\%) saw downgrades to their bond ratings. Three projects $(20 \%)$ have defaulted on their debt. Three projects $(20 \%)$ have already been liquidated at significant losses. 
An analysis of the reasons for success and failure suggests that the ability to generate revenue played the most significant role. Efficiency in capital costs and operating efficiency appear to have exerted less influence over the results.

These results suggest that decisionmakers should carefully assess the possibility that a municipal fiber network might struggle and include the costs associated with dealing with that outcome when deciding whether to initiate such a project. At a minimum, this study suggests that adequate due diligence would require an analysis of whether the current project more closely resembles the projects that succeeded or failed. This analysis should be premised on the documented reality that a project will not rapidly gain subscribers following launch and the economic reality that that an incumbent's natural response to entry by a new market competitor is to drop price. Practically, our study underscores the importance of municipalities considering whether to initiate a fiber project to focus on operational cash flow and not just the total capital expenditure of the project. Due diligence should also include consulting the municipal leaders of prior projects that struggled to reach short and long-term viability and establishing contingency plans in case a project fails to perform as expected.

Given the recent passage of the BIF, municipalities considering a municipal fiber project would also be well served to consider whether there are alternate and cost-effective means of ensuring that members of their communities have access stable and high-speed internet services. For example, in light of the recent availability of federal funds, municipal officials may determine that it is a more efficient use of public funds to offer subsidies to citizens in regions where an incumbent is already offering high-speed internet service.

Because the projects in this study consist entirely of overbuilds, these data say little about the prospects of greenfield projects in which the municipality is currently unserved by any 
incumbents. The fact that the BIF program prioritizes unserved areas over underserved areas make this omission critical. Whether greenfield municipal fiber projects would be more likely to succeed is unclear. On the one hand, greenfield projects necessarily involve areas other providers regard as relatively unattractive. On the other hand, greenfield projects would not face competition. This study does suggest that municipalities who are overbuilding competitors engage in a rigorous due diligence process (using proper financial metrics) to balance the short and long-term viability of the project and the benefits the community will receive from the proposed project. 


\section{References}

Balhoff, M.J., and Rowe, R.C. (2005). Municipal Broadband: Digging Beneath the Surface. Charlotte, NC: Balhoff \& Rowe, LLC. http://broadband.cti.gr/en/download/MunicipalBroadband—Digging\%20Beneath\%20the\%20Surface.pdf.

Beard, T.R., Ford, G.S., Spiwak, J.J., \& Stern, M. (2020). The law and economics of municipal broadband. Federal Communications Law Journal, 73(1), 1-98.

Beaver, W.H. (1966). Financial ratios as predictors of failure. Journal of Accounting Research 4(supp.): 71-111.

Bortolotti, B., D’Souza, J., Fantinic, M., and Megginson, W.L. (2002). Privatization and the sources of performance improvement in the global telecommunications industry. Telecommunications Policy 26(5-6): 243-268.

Chao, B., and Park, C. (2020). The Cost of Connectivity 2020. New America Foundation Open Technology Institute. https://www.newamerica.org/oti/reports/cost-connectivity-2020/.

City of Chattanooga. 2006. Official Statement Dated August 22, 2006, \$40,000,000 Electric System Revenue Bonds, Series 2006 A, \$23,430,000 Electric System Refunding Revenue Bonds, Series 2006 B.

Davidson, C.M., and Santorelli, M.J. (2014). Understanding the Debate over GovernmentOwned Broadband Networks: Context, Lessons Learned, and a Way Forward for Policy Makers. New York: ACLP at New York Law School. http://comms.nyls.edu/ACLP/ACLP-Government-Owned-Broadband-Networks-FINALJune-2014.pdf.

Executive Office of the President. (2015). Community-Based Solutions: The Benefits of Competition and Choice for Community Development and Highspeed Internet Access. https://obamawhitehouse.archives.gov/sites/default/files/docs/communitybased_broadband_report_by_executive_office_of_the_president.pdf.

Fiber-to-the-Home Council. (2009). Letter from Joe Savage, President, FTTH Council, to Marlene H. Dortch, Secretary, Federal Communications Commission, December 23. https://www.fiberbroadband.org/d/do/930.

Ford, G.S. (2020). OTI's Cost of Connectivity 2020 Report: A Critical Review. Phoenix Center for Advanced Legal \& Economic Public Policy Studies Perspective No. 20-06. https://www.phoenix-center.org/perspectives/Perspective20-06Final.pdf.

Ford, G.S., and Seals R.A. (2021). The rewards of municipal broadband: An econometric analysis of the labor market. Telecommunications Policy, 45(8): 102220. 
Gonsalves, S. (2020). Chicago and Denver voters say yes to expanded broadband options. Community Networks, November 5. https://muninetworks.org/content/chicago-anddenver-voters-say-yes-expanded-broadband-options.

Governmental Accounting Standards Board. (1989). Statement No. 9 of the Government Accounting Standards Board: Reporting Cash Flows of Proprietary and Nonexpendable Trust Funds and Governmental Entities That Use Proprietary Fund Accounting, September. https://www.gasb.org/jsp/GASB/Document_C/DocumentPage?cid=1176160030344.

Guidry, B.N., Carson, P.P., and Haon, C. (2012). Economic implications of FTTH networks: A cross-sectional analysis. Journal of Economic \& Social Policy, 15(1): 106-131.

Holcombe, A.N. (1911). Public Ownership of Telephones on the Continent of Europe. Boston: Houghton Mifflin.

Holt, L., and Jamison, M. (2009). Broadband and contributions to economic growth: Lessons from the US experience. Telecommunications Policy, 33(10-11): 575-581.

Janson, M.A., and Yoo, C.S. (2013). The wires go to war: The U.S. experiment with government ownership of the telephone system during World War I. Texas Law Review, 91(5): 983 1050.

Jassem, H.C. (2010). Municipal Wi-Fi: The coda. Journal of Urban Technology, 71(2): 3-20.

Kenny, R., and Kenny, C. (2011). Superfast broadband: Is it really worth a subsidy?, info, 13(4): 3-29.

Lenard, T.M. (2004). Government entry into the telecom business: Are the benefits commensurate with the costs?, Progress on Point, 11(3): 1-31. http://www.pff.org/issues-pubs/pops/pop11.3govtownership.pdf.

Lohr, S. (2010). Fastest net service in U.S. coming to Chattanooga. New York Times, September 12.

Mitchell, C. (2012). Broadband at the Speed of Light: How Three Communities Built NextGeneration Networks. Washington, DC: Institute for Local Self-Reliance. http://ilsr.org/wp-content/uploads/2012/04/muni-bb-speed-light.pdf.

Montagne, R., and Chaillou, V. (2010). Public funding \& FTTH: Assessing the impact of public action. Communications \& Strategies, 80(4): 153-161.

Noll, R.G. (2000). Telecommunications Reform in Developing Countries. In A.O. Krueger, ed., Economic Policy Reform: The Second Stage. Chicago: University of Chicago Press, pp. $183-242$. 
Oh, S. (2019). What are the economic effects of municipal broadband?, Paper presented at TPRC47: The 47th Research Conference on Communication, Information and Internet Policy. https://ssrn.com/abstract=3426247.

Scott, B., and Wellings, F. (2005). Telco Lies and the Truth About Municipal Broadband Networks. Washington, DC: Free Press. http://www.freepress.net/sites/default/files/fplegacy/mb_telco_lies.pdf.

Talbot, D.A., Hessekiel, K.H., and Kehl, D.L. (2018). Community-Owned Fiber Networks: Value Leaders in America. Berkman Klein Center for Internet \& Society Research Publication. https://cyber.harvard.edu/publications/2018/01/communityfiber.

U.S. Federal Communications Commission. (2000). 1998 Biennial Regulatory Review—Review of Depreciation Requirements for Incumbent Local Exchange Carriers, Report and Order. Federal Communications Commission Record, 15(1): 242-280. https://docs.fcc.gov/public/attachments/FCC-99-397A1.pdf

U.S. Government Accountability Office. (2012). Planning and Flexibility Are Key to Effectively Deploying Broadband Conduit Through Federal Highway Projects. https://www.gao.gov/assets/gao-12-687r.pdf.

U.S. Government Accountability Office. (2014). Telecommunications: Federal Broadband Deployment Programs and Small Business. https://www.gao.gov/products/gao-14-203.

U.S. Internal Revenue Service. (2021). Publication 946: How to Depreciate Property. https://www.irs.gov/pub/irs-pdf/p946.pdf.

U.S. Securities and Exchange Commission. (2021). Investor Bulletin: Municipal Bonds: Understanding Credit Risk. https://www.investor.gov/introduction-investing/generalresources/news-alerts/alerts-bulletins/investor-bulletins-66.

Yoo, C.S., and Pfenninger, T. (2017a). Municipal fiber in the United States: An empirical assessment. http://ssrn.com/abstract=2944137.

Yoo, C.S., and Pfenninger, T. (2017b). Municipal fiber in the United States: Response to critics and extension of the analysis. https://www.law.upenn.edu/live/files/6674-yoo-pfenninger--response. 